\title{
Polymyalgia rheumatica and rheumatoid arthritis of the elderly: a clinical, laboratory, and scintigraphic comparison
}

\author{
H Häntzschel, H A Bird, W Seidel, W Krüger, G Neumann, G Schneider, V Wright
}

\begin{abstract}
Clinical, laboratory, and scintigraphic features of 16 patients with polymyalgia rheumatica and 23 patients matched for age presenting with classical or definite rheumatoid arthritis (American Rheumatism Association 1958 criteria) of the elderly were compared in order to define features that might distinguish between these two syndromes.

The sensitivity of proposed diagnostic criteria for polymyalgia rheumatica was always higher in the group with polymyalgia rheumatica, though only significantly so for morning stiffness. A comparison of 27 different laboratory features showed few significant differences between the diseases, though correlation between laboratory variables within each of the disease groups differed, perhaps suggesting a fundamental pathogenetic difference between them. Scintigraphy of the shoulder joint proved of no value in differential diagnosis.

It was concluded that polymyalgia rheumatica and rheumatoid arthritis of the elderly are probably discrete clinical entities. Bilateral upper arm tenderness, lack of positive rheumatoid factor, and a normal caeruloplasmin are the most valuable features for distinguishing polymyalgia rheumatica from rheumatoid arthritis of the elderly.
\end{abstract}

Division of

Rheumatology,

Medical Policlinical

Institute,

Kart-Marx-University,

Leipzig, Germany

H Häntzschel

W Seidel

W Krüger

Division of Nuclear

Medicine,

Clinic of Radiology,

Kart-Marz-University,

Leipzig, Germany

G Neumann

G Schneider

Rheumatology and

Rehabilitation

Research Unit,

University of Leeds,

United Kingdom

H A Bird

V Wright

Correspondence to:

Dr H A Bird,

University of Leeds,

Clinical Pharmacology Unit,

Royal Bath Hospital,

Harrogate, North Yorks HG1 2PS.

Accepted for publication 12 July 1990
Polymyalgia has always been a great mimic. Bagratuni's early description was of the 'anarthritic rheumatoid syndrome'. 1 Subsequently, the distinct clinical features of polymyalgia rheumatica became better appreciated, ${ }^{2}$ leading to the formulation of diagnostic criteria for the syndrome $e^{3}$ that clearly delineated it from rheumatoid arthritis as defined by the earlier 1958 criteria from the American Rheumatism Association (ARA). ${ }^{4}$ matica can occur in patients with well established classic rheumatoid arthritis, 56 just as rheumatoid arthritis can develop in patients who have previously presented with polymyalgia rheumatica. ${ }^{78}$ More controversially, some patients present with a syndrome mimicking both diseases, ${ }^{9}$ and in recent years majority opinion has moved towards the concept of a continuous spectrum of disease with polymyalgia rheumatica and rheumatoid arthritis occupying divergent ends. ${ }^{1011}$

In an attempt to define clinical, laboratory, and scintigraphic features that might aid in further distinguishing the two conditions we compared a group of patients with polymyalgia
It is now accepted that polymyalgia rheu- rheumatica according to standard criteria ${ }^{3}$ with a group of patients who displayed classical or definite rheumatoid arthritis according to ARA criteria ${ }^{4}$ but who were matched for age with the patients with classical polymyalgia rheumatica.

\section{Patients and methods}

PATIENTS

A detailed history, clinical examination, and laboratory evaluation with scintigraphy was undertaken in 16 patients with polymyalgia rheumatica and 23 patients with rheumatoid arthritis of the elderly. Two of the 16 patients with polymyalgia rheumatica had temporal arteritis. All other patients had classical or definite rheumatoid arthritis (ARA criteria), ${ }^{4}$ were aged 60 or more, and showed evidence of moderate disease activity defined by the presence of at least three of the following six criteria: (a) tenderness of more than three joints; (b) swelling of more than three joints; (c) morning stiffness for more than 45 minutes; (d) articular index greater than 20; (e) erythrocyte sedimentation rate greater than $28 \mathrm{~mm} / \mathrm{h}$; (f) C reactive protein more than $20 \mathrm{mg} / \mathrm{l}$.

Of 23 patients with rheumatoid arthritis of the elderly, 22 were female. Their mean age was 69 (range 60-88) years and the mean disease duration two years. All 16 patients with polymyalgia rheumatica were female, mean age 66 (range 56-76) years with a mean disease duration of six months. Patients with rheumatoid arthritis of the elderly had a positive rheumatoid factor (mean titre 1/548) with significant differences for all three rheumatoid factor tests compared with patients with polymyalgia rheumatica (mean titre 1/56).

CLINICAL ASSESSMENTS

Patients were examined in a rheumatology outpatient clinic and the results compared with the diagnostic criteria for polymyalgia rheumatica proposed by Bird et $a l^{3}$ : (a) bilateral shoulder pain or stiffness, or both; $(b)$ duration of onset of two weeks or less; (c) initial erythrocyte sedimentation rate greater than $\mathbf{4 0}$ $\mathrm{mm} / \mathrm{h} ;(d)$ duration of stiffness greater than one hour; $(e)$ age 65 or more; $(f)$ depression or weight loss, or both; $(g)$ bilateral upper arm tenderness.

Definite polymyalgia rheumatica is defined as probable polymyalgia rheumatica (any three or more of these criteria or less than three criteria with clinical abnormality of the temporal artery) with a positive response to steroid treatment using a single blind therapeutic test of steroid against placebo. 
BIOCHEMICAL AND IMMUNOLOGICAL ASSESSMENTS Before treatment the following were recorded:

(a) routine haematological parameters;

(b) routine biochemical parameters (including serum electrophoresis);

(c) C reactive protein, haptoglobin, $\alpha_{1}$ acid glycoprotein, antitrypsin (measured by radial immunodiffusion);

(d) mucoproteins and $N$-acetylneuraminic acid (Pharmacopoeia of the GDR: Diagnostic Laboratory Methods, 1983);

(e) caeruloplasmin (enzyme method using $p$ phenylenediamine);

(f) copper (atomic absorption spectrometry);

(g) iron binding capacity (spectrophotometric method, Pharmacopoeia of the GDR: Diagnostic Laboratory Methods, 1983);

(h) total protein (biuret method) and plasma protein electrophoresis (cellulose acetate foil electrophoresis, Pharmacopoeia of the GDR: Diagnostic Laboratory Methods, 1983);

(i) total sulphydryl;

(j) histidine (spectrofluorometric method);

(k) antinuclear factor (Institute of Clinical Immunology, Karl Marx University of Leipzig);

(l) rheumatoid factors (Institute of Medical Microbiology and Experimental Therapy of Academy of Science of the GDR, Jena): Podliachouk-Harboe-test, acryl fixation test, latex fixation test.

All biochemical and immunological assays were performed in Leipzig except for determination of rheumatoid factors which was carried out in Jena, and for the serum histidine which was measured in Leeds on samples that had been stored and transported in batches at $-20^{\circ} \mathrm{C}$.
SCINTIGRAPHIC ASSESSMENTS

Patients were assessed in the division of nuclear medicine of the clinic of radiology, Karl Marx University of Leipzig using standard technetium-99m pertechnetate scintigraphs for the shoulder joints.

\section{STATISTICAL METHODS}

Two sample analysis (mean value, $\mathrm{SD}, \mathrm{SE}$ ) and Pearson correlation coefficients $(r)$ were used.

\section{Results}

Table 1 shows the normal range, mean values, and standard deviation of clinical and laboratory variables. For laboratory variables significant differences between the two groups occurred only for rheumatoid factor titre and for caeruloplasmin concentration, which was increased in patients with rheumatoid arthritis of the elderly. There was a tendency for a higher prevalence of clinical symptoms, such as bilateral shoulder pain or stiffness, or both, an acute onset of illness (two weeks or less), and bilateral upper arm tenderness in patients with polymyalgia rheumatica.

Patients with rheumatoid arthritis of the elderly had a higher concentration of mucoproteins, $\mathrm{C}$ reactive protein, and caeruloplasmin than patients with polymyalgia rheumatica, though perhaps owing to the small patient group size and large standard deviation, the differences between the mean values were not significant except for caeruloplasmin $(\mathrm{p}=0.03)$. No differences were seen between the two patient groups for erythrocyte sedimentation rate, total protein, plasma protein electrophoresis, histidine, total sulphydryl, serum

Table 1 Mean values (SD) and two sample analysis results in patients with rheumatoid arthritis of the elderly and polymyalgia rheumatica

\begin{tabular}{|c|c|c|c|c|c|}
\hline $\begin{array}{l}\text { Variable } \\
\text { (normal range, unit) }\end{array}$ & $\begin{array}{l}R A E^{*} \\
(n=23\end{array}$ & & $\begin{array}{l}P M R \\
(n=16\end{array}$ & & $\begin{array}{l}\text { Two sample } \\
\text { analysis results }\end{array}$ \\
\hline $\begin{array}{l}\mathrm{ESR}^{*}(\mathrm{~mm} / \mathrm{h}) \\
\text { Rheumatoid factor }\end{array}$ & $56 \cdot 4$ & $(40 \cdot 4)$ & 54.9 & $(28 \cdot 8)$ & NS \\
\hline $\begin{array}{l}\text { Podliachouck-Harboe test }(1 / \mathbf{n}) \\
\text { Acryl fixation test }(1 / \mathrm{n}) \\
\text { Latex fixation test }(1 / \mathrm{n}) \\
\text { Total protein }(<85 \mathrm{~g} / \mathbf{l}) \\
\text { Albumin }(0.56-0.66)\end{array}$ & $\begin{array}{l}548 \\
514 \\
608 \\
73 \\
0 \cdot 042\end{array}$ & $\begin{array}{l}(600) \\
(491) \\
(664) \\
(67 \cdot 8) \\
(0 \cdot 06)\end{array}$ & $\begin{array}{l}56 \\
60 \\
56 \\
71 \cdot 7 \\
0 \cdot 44\end{array}$ & $\begin{array}{l}(130) \\
(130) \\
(90) \\
(46 \cdot 3) \\
(0 \cdot 04)\end{array}$ & $\begin{array}{l}0 \cdot 002 \\
0 \cdot 0009 \\
0 \cdot 002 \\
\text { NS } \\
\text { NS }\end{array}$ \\
\hline 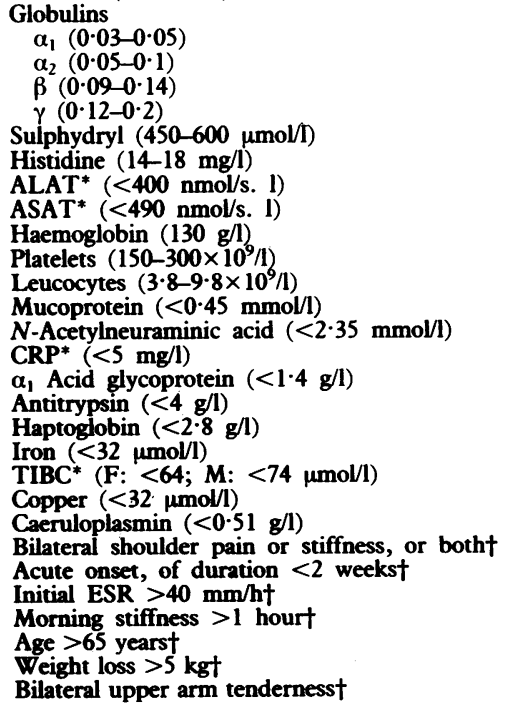 & $\begin{array}{l}0 \cdot 04 \\
0 \cdot 16 \\
0 \cdot 17 \\
0 \cdot 21 \\
0 \cdot 32 \\
13 \cdot 5 \\
407 \\
323 \\
124 \\
197 \cdot 4 \\
8 \cdot 9 \\
1 \cdot 14 \\
2 \cdot 69 \\
42 \cdot 2 \\
1 \cdot 53 \\
3 \cdot 1 \\
4 \cdot 6 \\
10 \cdot 6 \\
53 \cdot 4 \\
26 \cdot 6 \\
0 \cdot 7 \\
65 \\
30 \\
52 \\
79 \\
74 \\
48 \\
26\end{array}$ & $\begin{array}{l}(0 \cdot 01) \\
(0 \cdot 03) \\
(0 \cdot 03) \\
(0 \cdot 05) \\
(0 \cdot 07) \\
(2 \cdot 2) \\
(270) \\
(165 \cdot 5) \\
(21) \\
(66 \cdot 5) \\
(3 \cdot 4) \\
(1 \cdot 8) \\
(0 \cdot 6) \\
(48) \\
(0 \cdot 7) \\
(1 \cdot 5) \\
(1 \cdot 9) \\
(6 \cdot 0) \\
(13 \cdot 2) \\
(8 \cdot 6) \\
(0 \cdot 4)\end{array}$ & $\begin{array}{l}0 \cdot 037 \\
0 \cdot 14 \\
0 \cdot 18 \\
0 \cdot 20 \\
0 \cdot 4 \\
13 \cdot 1 \\
408 \\
368 \\
114 \\
179 \cdot 9 \\
8 \cdot 9 \\
0 \cdot 58 \\
2 \cdot 29 \\
32 \cdot 2 \\
1 \cdot 44 \\
2 \cdot 9 \\
3 \cdot 7 \\
13 \cdot 1 \\
54 \cdot 3 \\
24 \cdot 6 \\
0 \cdot 5 \\
88 \\
57 \\
63 \\
50 \\
63 \\
38 \\
75\end{array}$ & $\begin{array}{l}(0 \cdot 01) \\
(0 \cdot 02) \\
(0 \cdot 02) \\
(0 \cdot 03) \\
(0 \cdot 09) \\
(2 \cdot 8) \\
(274) \\
(165 \cdot 1) \\
(34) \\
(56 \cdot 1) \\
(3 \cdot 4) \\
(0 \cdot 2) \\
(0 \cdot 61) \\
(51 \cdot 1) \\
(1 \cdot 0) \\
(1 \cdot 1) \\
(2 \cdot 2) \\
(4 \cdot 8) \\
(19 \cdot 5) \\
(9 \cdot 2) \\
(0 \cdot 1)\end{array}$ & $\begin{array}{l}\text { NS } \\
\text { NS } \\
\text { NS } \\
\text { NS } \\
\text { NS } \\
\text { NS } \\
\text { NS } \\
\text { NS } \\
\text { NS } \\
\text { NS } \\
\text { NS } \\
\text { NS } \\
\text { NS } \\
\text { NS } \\
\text { NS } \\
\text { NS } \\
\text { NS } \\
\text { NS } \\
\text { NS } \\
\text { NS } \\
\text { o.03 } \\
\text { NS } \\
\text { NS } \\
\text { NS } \\
\text { NS } \\
\text { NS } \\
\text { NS } \\
\text { NS }\end{array}$ \\
\hline
\end{tabular}

${ }^{*} \mathrm{RAE}=$ rheumatoid arthritis of the elderly; $\mathrm{PMR}=$ polymyalgia rheumatica; $\mathrm{ESR}=$ erythrocyte sedimentation rate; $\mathrm{ALAT}=$ serum ${ }^{2} \mathrm{RAE}=$ rheumatoid arthritis of the elderly; $\mathrm{PMR}=$ polymyalgia rheumate $\mathrm{CRP}=\mathrm{C}$ reactive protein; $\mathrm{TIBC}=$ total iron binding capacity. alanine aminotransferase; ASAT
tPercentage of patients shown 
Table 2 Sensitivity of the proposed diagnostic criteria in the two patient groups

\begin{tabular}{|c|c|c|c|}
\hline \multirow[t]{2}{*}{ Diagnostic criteria } & \multicolumn{2}{|c|}{ Sensitivity (\%) } & \multirow[t]{2}{*}{$x^{2}$} \\
\hline & $P M R^{*}$ & $R A E^{*}$ & \\
\hline $\begin{array}{l}\text { Bilateral shoulder pain or stiffness, or both } \\
\text { Duration of onset of two weeks or less } \\
\text { Initial ESR* greater than } 40 \mathrm{~mm} / \mathrm{h} \\
\text { Duration of stiffness greater than one hour } \\
\text { Depression or weight loss, or both } \\
\text { Bilateral upper arm tenderness }\end{array}$ & $\begin{array}{l}83 \\
42 \\
58 \\
58 \\
25 \\
75\end{array}$ & $\begin{array}{l}56 \\
25 \\
38 \\
69 \\
44 \\
13\end{array}$ & $\begin{array}{l}2 \cdot 3 \mathrm{NS} \\
0.9 \mathrm{NS} \\
1 \cdot 2 \mathrm{NS} \\
0.3 \mathrm{NS} \\
1 \cdot 1 \mathrm{NS} \\
11 \cdot 2 \mathrm{p}<0.01\end{array}$ \\
\hline
\end{tabular}

${ }^{*} \mathrm{PMR}=$ polymyalgia rheumatica; $\mathrm{RAE}=$ rheumatoid arthritis of the elderly; $\mathrm{ESR}=$ erythrocyte sedimentation rate. allowed an initial comparison of 146 patients with 'classical polymyalgia rheumatica' and 253 patients with conditions that mimic polymyalgia rheumatica. To perform well a criterion was required to have both high sensitivity and high specificity. From this analysis provisional criteria were selected. Criteria were refined on the basis of a second analysis of a further 90 patients with 'classical polymyalgia rheumatica' and 201 consecutive new patients. It was also suggested that a standardised therapeutic trial of prednisolone might have additional value in confirming the diagnosis of polymyalgia rheumatica.

In this study significant differences between the mean values for the two patient groups occurred only for rheumatoid factor and caeruloplasmin. The difference in rheumatoid factor is largely explained by the selection criteria used. There was a tendency towards a higher prevalence of clinical symptoms in patients with polymyalgia rheumatica. Patients with rheumatoid arthritis of the elderly had a higher concentration of mucoproteins, $\mathrm{C}$ reactive protein and caeruloplasmin, and there was a reduced haemoglobin in both patient groups.

The significant correlations within acute phase reactions for the group of patients with rheumatoid arthritis of the elderly is perhaps in keeping with the pathogenesis of this condition as an inflammatory joint disease with systemic features, particularly affecting the reticulohistiocytic system. By contrast, the lack of correlation between acute phase reactants for the group with polymyalgia rheumatica may suggest a different pathogenetic mechanism. Our results also suggest a different mechanism for the pathogenesis of the anaemia in the two groups.

Among 90 patients with polymyalgia rheumatica Günther et $a l^{12}$ only occasionally found rheumatoid factor and so recommended its use for the differential diagnosis from rheumatoid arthritis. The fall in mean erythrocyte sedimentation rate from 74 (range 20-144) to 28 (range $5-104$ ) $\mathrm{mm} / \mathrm{h}$ after one month's treatment with corticosteroids was also of value in diagnosis. $C$ reactive protein and $\alpha_{2}$ globulins were often raised and serum alanine, aminotransferase, serum aspartate aminotransferase, and $\gamma$-glutamyltranspeptidase were raised in $6 \%$ of his patients. In our study patients with polymyalgia rheumatica showed a significant negative correlation between serum alanine aminotransferase and albumin $(r<0.06)$. Significant positive correlations between $\gamma$ globulins and serum alanine aminotransferase $(r=0 \cdot 8)$ and $C$ reactive protein $(r=0.5)$ also occurred. In the group with rheumatoid arthritis of the elderly the serum alanine aminotransferase showed significant correlations with the erythrocyte sedimentation rate $(r=0.5)$ and $C$ reactive protein $(r=0.5)$. In agreement with Günther $e t a^{12}$ we also found the platelet count to be an indicator of disease activity in rheumatoid arthritis of the elderly as it correlates with acute phase reactants.

Since the planning and execution of this study new diagnostic criteria have been proposed by the American Rheumatism Association (1987). ${ }^{13}$ These place less reliance upon

The earlier multicentre study to evaluate diagnostic criteria for polymyalgia rheumatica ${ }^{3}$ 
invasive diagnostic features and attempt to improve the sensitivity and, in particular, the specificity of the earlier criteria. ${ }^{4}$ Only six patients with polymyalgia rheumatica are included in the extensive control groups selected to validate these criteria, a point conceded by the authors in their discussion. They argue that lack of rheumatoid nodules, the presence of rheumatoid factor, and the presence of radiographic erosions together with an excellent clinical response to low dose corticosteroid treatment may still remain the most useful features in differential diagnosis, though this suggestion still awaits validation. Our own results suggest additional laboratory features that may also be of value.

Our results lend support to the concept of rheumatoid arthritis of the elderly and polymyalgia rheumatica as discrete disease entities, provided that appropriate diagnostic criteria are used, even though the evidence from gene polymorphism ${ }^{14}$ may be more supportive of the concept of a continuous disease spectrum. Further studies, applying the features we found to be of most distinctive value to those patients who occupy an intermediate position in this spectrum, would be of interest to determine whether our features offer additional help with diagnosis and also with prognosis.
1 Bagratuni L. Prognosis in the anarthritic theumatoid syndrome. $B M \mathcal{F}$ 1963; i: 13-18.

2 Mowat A G, Hazleman B L. Polymyalgia rheumatica-a clinical study with particular reference to arterial disease. $\mathcal{F}$ clinical study with particular

3 Bird H A, Esselinck W, Dixon A S, Mowat A G, Wood P H. An evaluation of criteria for polymyalgia rheumatica. Ann Rheum Dis 1979; 38: 434-9.

4 Ropes M W, Bennett G A, Cobb S, Jacox R, Jessar R A. 1958 Revision of diagnostic criteria for rheumatoid arthritis. Arthritis Rhewon 1959; 2: 16-20.

5 Palmer R G, Prouse P J, Gumpel J M. Occurrence of polymyalgia rheumatica in theumatoid arthritis. $B M \mathcal{F}$ 1986; 292: 867

6 Robbins $D \mathrm{~L}$, White $\mathrm{R} H$. Interrelationships between polymyalgia rheumatica and polyarthritis. $\mathcal{f}$ Rheumatol 1988; 15: 1323-5.

7 Healey L A. Long term follow-up of polymyalgia rheumatica: evidence for synovitis. Semin Arthritis Rheum 1984; 13: 322-8

8 Henderson D R F, Tribe C R, Dixon A St J. Synovitis in polymyalgia rheumatica. Rheumatology and Rehabilitation 1975; 14: 244-50.

9 Bird H A. Polymyalgia rheumatica and temporal arteritis. In: Wright V, ed. Bone and joint disease in the elderly. Edinburgh, London, Melbourne and New York: Churchill Livingstone, 1983: 60-79.

10 Healey L A, Sheets P K. The relation of polymyalgia rheumatica to rheumatoid arthritis. $\mathcal{J}$ Rheumatol 1988; 15: rheum 2 .

11 Healey $\mathbf{L}$ A. Late onset $R A$ versus polymyalgia rheumatica. Geriatric Medicine 1989; 19: 59-65.

12 Günther R, Tischler M, Herold M. Polymyalgia rheumaticaKlinische Beobachtungen an 90 Patienten. $Z$ Rheumatol 1985; 44: 218-25.

13 Arnett F C, Edworthy S T, Bloch D A, et al. The American Rheumatism Association 1987 revised criteria for the 31: $315-24$.

14 Sakkas L I, Loqueman N, Panayi G S, Welsh K I. HLADRB, -DQA, -DQB gene polymorphisms in polymyalgia rheumatica [Abstract]. $\mathrm{Br} \mathcal{F}$ Rherumatol 1989; 18 (suppl 2): 50 . 